\title{
PENGARUH PENAMBAHAN ADITIF ETANOL PADA BENSIN RON 88 DAN RON 92 TERHADAP PRESTASI MESIN
}

\author{
Yos Nofendri \\ Program Studi Teknik Mesin,Fakultas Teknik,Universitas 17 Agustus 1945 \\ Jakarta \\ e-mail :yosnofendri@gmail.com
}

\begin{abstract}
ABSTRAK
Konsumsi bahan bakar fosil (fossil fuel) memunculkan paling sedikit dua ancaman serius yaitu faktor ekonomi berupa jaminan ketersediaan bahan bakar fosil untuk masa yang akan dating yang membuat harga mengalami fluktiasi serta polusi akibat emisi pembakaran bahan bakar fosil ke lingkungan. Untuk itu diperlukan bahan bakar non fosil untuk mengatasi masalah tersebut.Penelitian ini bertujuan mengetahui bagaimana pengaruh penambahan ethanol sebagai bahan bakar non-fosilyang dicampurkan ke dalam bensin RON92 dan RON 88 sebanyak 5\% dan 10\% untuk mengetahui pengaruh terhadap sifat bahan bakar (Research Oktane Number, Densitas, Nilai Kalori Bakar) dan performa mesin (daya, torsi, konsumsi bahan bakar dan efisiensi termal). Penelitian ini menggunakan mesin bensin yang disambungkan dengan hydrobrake untuk mengetahui performa mesin dengan putaran $1000 \mathrm{rpm}, 1500 \mathrm{rpm}, 2000 \mathrm{rpm}, 2500 \mathrm{rpm}$, 3000 rpm. Hasil penelitian menunjukan bahwa penambahan ethanol dalam premium dan pertamax dapat mempengaruhi sifat dari bahan bakar baik pada jenis pertamax maupun pada premium. Penambahan etanol.Berdasarkan hasil penelitian ini, dapat disarankan pengembangan penggunaan sumber energi alternative terutama ethanol yang memiliki persediaan yang cukup banyak sehingga sedikit demi sedikit menguranggiketergantugan terhadap bahan bakar fosil terutama minyak bumi yang semakin hari semakin menipis persediaannya.
\end{abstract}

Kata Kunci : Motor Bakar, Bensin, Etanol, Performa Mesin

\section{PENDAHULUAN}

Lebih darisembilan puluh persen kebutuhan energi dunia dipasok dari bahan bakar fosil. Jika eksploitasi terus berjalan dengan angka saat ini, diperkirakan sumber energi ini akan habis dalam lima puluh tahun mendatang (Andal Yakinudin. 007). Untuk itu, banyak negara-negara maju mulai mengembangkan sumber energi baru terbaharukan, ramah lingkungan, dan mudah untuk dibuat serta bahan bakunya yang masih tersedia banyak. Sumber energi baru terbarukan itu adalah etanol. Etanol sebenarnya bukan barang baru lagi.

Pemilihan BBM yang tepat untuk kendaraan kita adalah dengan penggunaan angka oktan yang harus disesuaikan dengan tekanan kompresi kendaraan yang kita gunakan. Semakin tinggi kompresi kendaraan tersebut maka sebaiknya menggunakan bahan bakar berangka oktan tinggi. Maka, untuk kendaraan yang mempunyai kompresidibawah 9:1 masih bisa menggunakan bahan bakar bensin berjenis premium akan tetapi untuk kendaraan dengan kompresi 9,1:1 sampai
10:1 sebaiknya menggunakan pertamax 96 atau sejenisnya dan kendaraan berkompresi 10,1 keatas sebaiknya menggunakan pertamax plus atau pertamax turbo atau sejenisnya (Y.Efendi : 2007).

Kendaraan dengan spesifikasi bahan bakar Pertamax atau pertamax plus jika menggunakan Premium, maka performa mesin dan umur pakai mesin akan berkurang. Akan tetapi jika kendaraan yang berkompresi rendah dengan spesifikasi bahan bakar Premium jika menggunakan Pertamax, maka tidak begitu berpengaruh terhadap besar pada performa mesin hanya saja suhu mesin lebih panas. Penggunaan kadar oktan yang tidak sesuai dapat menyebabkan piston menjadi berlubang.

Pada (2005) Atok Setiyawan melakukan penelitian campuran premium, pertamax dan etanol dengan presentase etanol (15\% dan $85 \%)$ dan premium $(70 \%$ dan $30 \%$ ) dengan memvariasikan diameter main jet. Penulis membandingkan campuran Etanol dengan premium dan pertamax plus sebagai octane tertinggi, dimana hasilnya menunjukan bahwa etanol mempunyai unjuk kerja lebih rendah tetapi knocking yang yang 
dihasilkanlebih tinggi dibandingkan Pertamax plus.

\subsection{Motor Bakar}

Motor bensin termasuk kedalam jenis motorbakar torak. Proses pembakaran bahan bakar dan udara terjadi didalam silinder (internal combustion engine). Motor bakar bensin dilengkapi dengan busi dan karburator yang membedakan dengan motor disel. Motor bensin dibagi dalam dua jenis yaitu motor bensin 2 langkah dan motor bensin 4 langkah. Motor 2 langkah adalah motor yang dalam siklus kerjanya membutuhkan 1 kali putaran poros engkol dan menghasilkan 1 langkah usaha. Sedangkan motor bensin 4 langkah adalah motor yang dalam satu siklus kerjanya membutuhkan 2 kali putaran poros engkol dan menghasilkan 1 kali langkah usaha.

Bahan bakar premium yang dibuat pada suatu kilang umunya diproduksi sesuai dengan mutu yang telah ditentukan, tetapi kualitasnya masih ada kemungkinan untuk ditingkatkan. Salah satu cara adalah dengan penambahan zat aditif pada bahan bakar. Sehingga perlu dilakukan riset untuk membuktikan jika bahan bakarnya ditambahkan zat aditif (etanol). Penelitian mengenai penambahan zat aditif pada bahan bakar motor bakar dengan dilakukan untuk mengetahui pengaruh performa motor bakar bensin yang meliputi: torsi, daya, konsumsi bahan bakar serta konsumsi bahan bakar spesifik. Hasi. Riset menunjukkan bahwa torsi sebagai fungsi putaran poros mesin pada bahan bakar motor bakar bensin yang dicampur dengan zat aditif lebih besar $5 \%$ dibandingkan premium murni. Perhitungan konsumsi bahan bakar menunjukkan bahan bakar premium ditambah aditif sedikit lebih borospada kecepatan puratan mesin awal tetapi seiring bertambahnya kecepatan putaran mesin efisiensi juga bertambah.

\subsection{Etanol Sebagai Zat Aditif}

Etanol adalah zat aditif yang dihasilkan dari fermentasi glukosa yang dilanjutkan dengan proses destilasi. Etanol merupakan kependekan dari etil alkohol dengan rumus kimia $(\mathrm{C} 2 \mathrm{H} 5 \mathrm{OH})$. Sifat lainnya adalah larut dalam air dan eter, berat jenisnya adalah sebesar $0,7939 \mathrm{~g} / \mathrm{mL}$, dan titik didihnya $78,320^{\circ} \mathrm{C}$ pada tekanan $766 \mathrm{mmHg}$, serta mempunyai panas pembakaran 7093.72 kkal.
Cepat atau lambat sumber minyak (fuel source) akan habis karena depositnya terbatas. Minyak bumi merupakan sumber energi yang tidak dapat diperbaharu. Keterbatasan itu mendorong negara industri melirik etanol (biofuel) sebagai sumber energi altenatif. Karena selain terus-menerus dapat diproduksi oleh mikroorganisme, etanol juga ramah lingkungan.

Tabel 1.1Sifat karakteristik etanol dan bensin

\begin{tabular}{|l|c|c|}
\hline Karakteristik & Etanol & Bensin \\
\hline Nilai Kalor (MJ/Kg) & 26,8 & 42 \\
\hline Angka Oktan (RON) & 108 & $88-96$ \\
\hline Berat Jenis $15^{\circ} \mathrm{C}\left(\mathrm{Kg} / \mathrm{dm}^{3}\right)$ & 0,79 & 0,76 \\
\hline Viskositas $20^{\circ} \mathrm{C}\left(\mathrm{mm}^{2} / \mathrm{s}\right)$ & 1,5 & 0,6 \\
\hline Presentase oksigen $(\%)$ & 35 & $0-2$ \\
\hline \multicolumn{2}{|r|}{ Sumber : McCormick.2001 } \\
\hline
\end{tabular}

\section{METODOLOGI PENELITIAN}

Penelitian ini menggunakan metode eksperimental dan metorda deskriptif dari data yang diperoleh dari pengujian

\subsection{Alat}

Alat yang dipakai dalam pengujian ini terdiri dari :

a. Gelas Ukur

Gelas ukur yang dipakai terdiri dari dua macam (ukuran) karena pada saat penakaran bahan bakar harus benar-benar tepat supaya data yang diambil benar-benar akurat.

b. Mesin Uji

Mesin LONCIN TYPE 2V78-1 678 CC merupakan mesin yang proses kerjanya menggunakan mesin 4 tak (4 stroke). Terdiri dari 2 silinder dengan kapasitas mesin 678 CC dengan rasio kompresi 8,5:1. Sebelum dilaksanakan penelitian, perlu diuji terlebih dahulu kecepatan putaran mesin yang digunakan. Kecepatan idle mesin adalah 1000Rpm, sedangkan kecepatan maksimum yang digunakan adalah 3000Rpm karena diatas kecepatan 3000Rpm, getaran mesin terlalu besar yang bisa merusak komponen pada mesin itu sendiri. Jadi kecepatan putaran mesin yang digunakan dalam pengujian ini adalah 1000Rpm - 3000Rpm dengan interval 500Rpm. 

c. Hydrobrake
d. Stopwatch
e. Gelas Pengukuran Bahan Bakar
f. Papan Perhitungan dalam Uji prestasi

\subsection{Bahan}

Bahan yang dipakai dalam pengujian ini terdiri dari bahan bakar bensin jenis RON 88 (premium) dan RON 92 (pertamax). Sedang kan aditif yang digunakan adalah etanol 96\%. Adapun jenis bahan bakar campuran yang diuji adalah sebagai berikut :

1. Premium sebagai bahan bakar utama (ME0)

2. Premium $95 \%+$ Ethanol 5\% (ME5)

3. Premium $90 \%$ + Ethanol 10\%(ME10)

4. Pertamax sebagai bahan bakar utama (XE0)

5. Pertamax $95 \%+$ Ethanol (5\%) (XE5)

6. Pertamax $90 \%+$ Ethanol (10\%) (XE10)

Pencampuran bahan bakar dan etanol diatas akan membentuk sifat karakteristik campuran yang baru. Besar nya perubahan sifat karakteristik campuran tergantung pada banyak nya kadar campuran antara bensin dan kadar etanol yang di campurkan. Untuk menentukan berat jenis ,nilai kalori rendah ( $L H V)$ dan RON bahan bakar campuran maka dapat dihitung dengan menggunakan formula sebagai berikut :

$\mathrm{RON} \mathrm{BB}$ X $=\mathrm{X} \cdot \mathrm{RON}_{\text {Etanol }}+(1-\mathrm{X}) \mathrm{RON}_{\text {Bensin }}$ (1)

$\mathrm{LHV} \mathrm{BB}_{\mathrm{X}}=\mathrm{X} . \mathrm{LHV}_{\text {Etanol }}+(1-\mathrm{X}) \mathrm{LHV}_{\text {Bensin }}$ (2)

$\rho B=X \cdot \rho_{\text {Etanol }}+(1-X) \rho_{\text {Bensin }}$

Untuk uji prestasi pula, data yang diperoleh bertujuan untuk menghitung variable uji prestasi sebagai berikut :

\section{Daya dan Torsi}

Tujuan dari pengamatan daya dan torsi adalah untuk mengetahui apakah daya dan torsi yang di hasilkan oleh motor bensindua silinder itu mengalami kenaikan atau penurunan sehingga kita bisa menghitung jumlah daya dan torsi yang di hasilkan berdasarkan masing-masing bahan bakar yang di ujikan.
Perhitungan untuk Torsi :

$$
\mathrm{T}=\mathrm{F} \times \mathrm{L}(\mathrm{N} . \mathrm{m})(4)
$$

Perhitungan untuk Daya :

$$
\mathrm{P}=\frac{2 \pi \cdot n \cdot T}{60000}(\mathrm{kw})(5)
$$

Torsi yang dihasilkan dapat dihitung setelah mendapatkan data tekanan yang ditunjukkan oleh hydrobrake yang dipasangkan pada poros engkol pada mesin. Data tekanan akan dikalikan dengan panjang lengan dimana panjang lengan ditetapkan oleh perancang alat uji prestasi yang digunakan pada penelitian ini sebesar $0.13 \mathrm{~m}$. Setelah nilai torsi diperoleh, maka nilai daya juga bisa dihitung dengan rumus yang melibatkan nilai torsi dan nilai putaran mesin yang tetapkan.

2. Konsumsi bahan bakar spesifik Brek (BSFC).

Jumlah bahan bakar yang diperlukan mesin tiap satuan waktu untuk menghasilkan daya sebesar 1kW.Perhitungan untuk BSFC :

$$
\mathrm{BSFC}=\frac{\mathrm{m}_{\mathrm{f}}}{\mathrm{p}}(\mathrm{kg} / \mathrm{kw} \cdot \mathrm{h})(6)
$$

Konsumsi bahan bakar spesifik brek dipengaruhi oleh laju aliran bahan bakar dan daya yang dihasilkan oleh mesin.

3. Efisiensi thermal ( $\left.n_{\text {th }}\right)$

Perbandingan energi kalor yang dirubah menjadi daya efektif dengan jumlah energi kalor bahan bakar yang disuplay ke dalam ruang bakar.

Perhitungan untuk effisiensi adalah :

$$
\eta_{\text {th }}=\frac{P}{\text { Qin }} \times 100 \%(7)
$$

effisiensi terma didapatkan setelah nilai daya yang dikeluarkan oleh mesin diperoleh dan nilai kalor yang dihasilkan oleh jumlah bahan bakar yang dimasukan kedalam ruang bakar. 


\subsection{Diagram Alir}

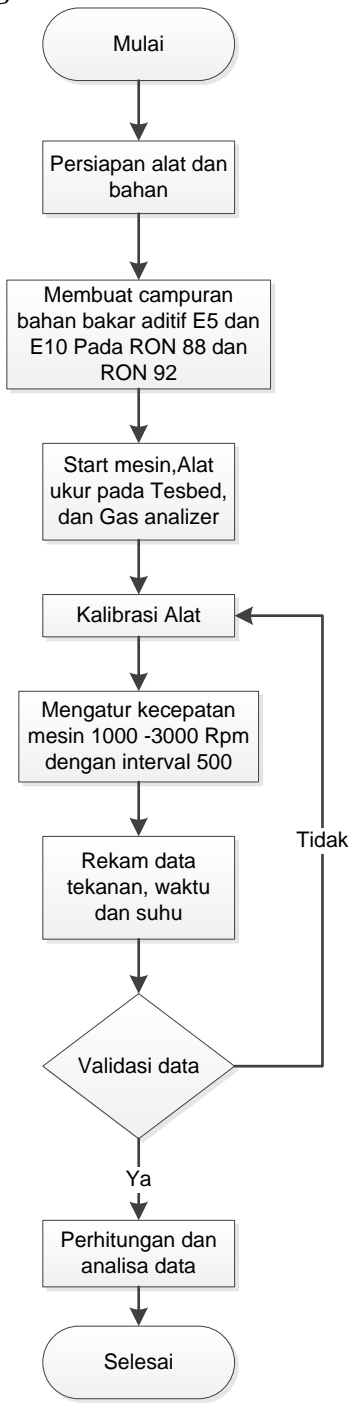

\subsection{Diagram Alir Penelitian}

\subsection{Langkah Pelaksanaan Penelitian}

Adapun langkah prosedur penelitian adalah sebagai berikut :

1. Memasangkan baterai (aki) pada mesin, aki disini di gunakan untuk menghidupkan mesin yang akan gunakan sebagai alat uji dalam uji prestasi mesin ini

2. Menyambungkan daya listrik pada terminal listrik yang telah disiapkan, daya listrik di perlukan untuk menghidupkan pompa air pada penampung air tujuannya agar sirkulasi air tetap berjalan, di samping itu aliran listrik di perlukan untuk menghidupkan papan perhitungan yaitu forcemeter, tachometer, temperature yang bersifat elektrik sehingga membutuhkan daya listrik.

3. Memasukan bahan bakar yang akan di ujikan dalam uji prestasi bahan bakar ini.

4. Mulai menghidupkan mesin uji prestasi.

5. Mulai mengatur kecepatan sesuai yang telah di tentukan yaitu 1000, 1500,2000, 2500, 3000 rpm. Pada tiap rpm kecepatan yang di tentukan kita mulai mengumpulkan data yang di

6. Menulis hasil yang di peroleh pada setiap kecepatan yang tampil pada papan perhitungan.

7. Mengukur pemkaian bahan bakar secara manual menggunakan stopwatch.

8. Setelah semua data yang di perlukan dalam satu bahan bakar di peroleh, maka akan di ganti dengan bahan bakar pembanding berikutnya dengan proses yang sama.

9. Dalam pengujian bahan bakar pembanding bahan bakar yang sebelumnya di uji kita buang terlebih dahulu, setelah itu kita masukan bahan bakar pembanding dan pada proses menyalakan mesin uji prestasi dengan bahan bakar pembanding kita memberi waktu 10-15 menit (toleransi) untuk membersihkan sisa dari bahan bakar sebelumnya.

\section{HASIL PENELITIAN}

\subsection{Karakteristik Bahan Bakar Campuran}

Tabel 3.1Sifat dan karakteristik bahan bakar

\begin{tabular}{|c|l|c|c|c|}
\hline No & $\begin{array}{c}\text { Jenis } \\
\text { Bahan } \\
\text { Bakar }\end{array}$ & RON & $\begin{array}{c}\text { Densitas } \\
\left(\mathrm{Kg} / \mathrm{m}^{3}\right)\end{array}$ & $\begin{array}{c}\text { LHV } \\
(\mathrm{M} . J)\end{array}$ \\
\hline 1 & ME5 & 89 & 0,780 & 43.891 \\
\hline 2 & ME10 & 90 & 0,780 & 42.991 \\
\hline 3 & XE5 & 93 & 0,741 & 41.818 \\
\hline 4 & XE5 & 94 & 0,744 & 41.028 \\
\hline
\end{tabular}

Setelah dilakukan perhitungan tentang sifat karakteristik bahan bakar campuran, maka dapat dilihat pencampuran bensin dan etanol menghasilkan sifa dan karakteristik bahan bakar yang baru. Sifat dan karakteristik bahan bakar campuran dapat dilihat pada tabel 3.1. Untuk nilai RON dan densitas campuran, penambahan etanol kedalam bensin, baik premium maupun pertamax bisa sedikit meningkatkan nilai RON dan densitas pada semua campuran. Ini diesebabkan nilai RON dan densitas pada 
etanol lebih tinggi dibanding dengan nilai RON dan densitas pada semua jenis bensin. Untuk nilai kalori bakar rendah (LHV) pada campuran bahan bakar terjadi penurunan. Ini disebabkan LHV etanol lebih rendah dari pada LHV pada kedua jenis bensin yang digunakan.

\subsection{Perbandingan Prestasi Mesin}

Data prestasi mesin diperoleh setelah semua jenis bahan bakar diujikan pada mesin. Data tersebut diolah dengan menggunakan perhitungan untuk memperoleh nilai torsi, daya, konsumsi bahan bakar spesifik brek (BFSC) dan effisiensi therma. Setelah data perhitungan uji prestasi diperoleh, maka dibuatkan grafik untuk membandingkan prestasi mesin menggunakan premium etanol dan pertamax etanol.

\subsubsection{Torsi dan Daya}

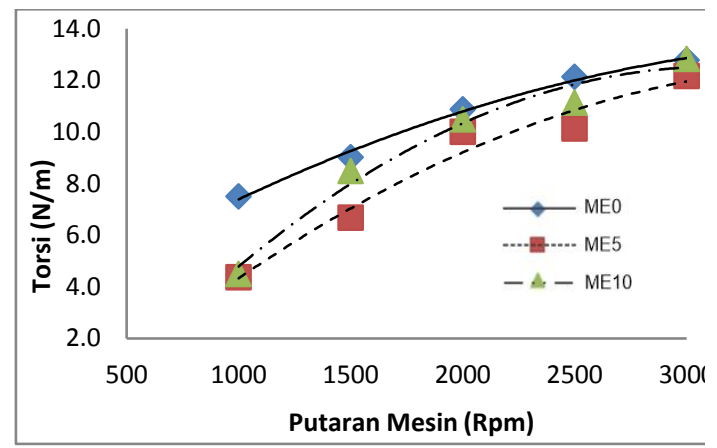

Gambar 3.1Grafik torsi vs putaran mesin untuk campuran premium etanol

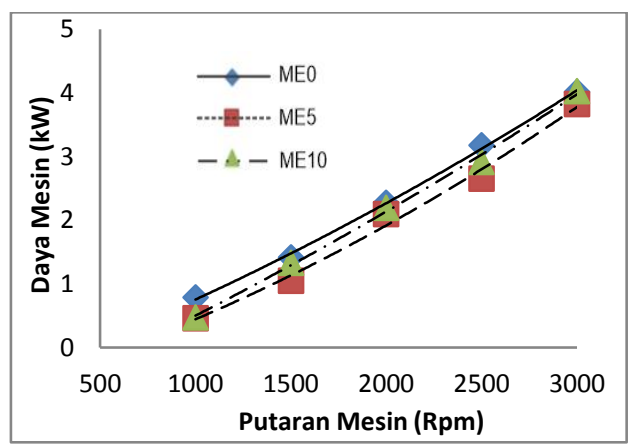

Gambar 3.2Grafik daya vs putaran mesin untuk campuran premium etanol

Untuk nilai torsi dan daya pada campuran bensin jenis premium dan etanol dapat dilihatpada gambar 3.1 dan 3.2. pada grafik tersebut terlihat bahwa terjadi kenaikan torsi dan daya pada semua putaran mesin baik pada jenis bahan bakar premium maupun pada jenis bahan bakar campuran bensin premium etanol. Pada gambar 3.1 dan 3.2 jugak dilihat penambahan etanol pada premium sedikit menurunkan torsi dan daya pada kedua-dua kadar penambahan etanol.

Pada grafik 3.1 dan 3.2 juga dapat dilihat garis ME0 berada diatas grafik ME5 dan ME10. Dengan melihat hasil penurunan nilai LHV pada campuran ME5 dan ME10 dapat menyebabkan terjadi penurunan nilai torsi, baik pada campuran ME5 maupun ME10. Pada ME5 terjadi penurunan sebanyak $17 \%$ dan XE1 terjadi penurunan sebanyak $9 \%$ jika dibandingkan dengan bensin tanpa campuran.

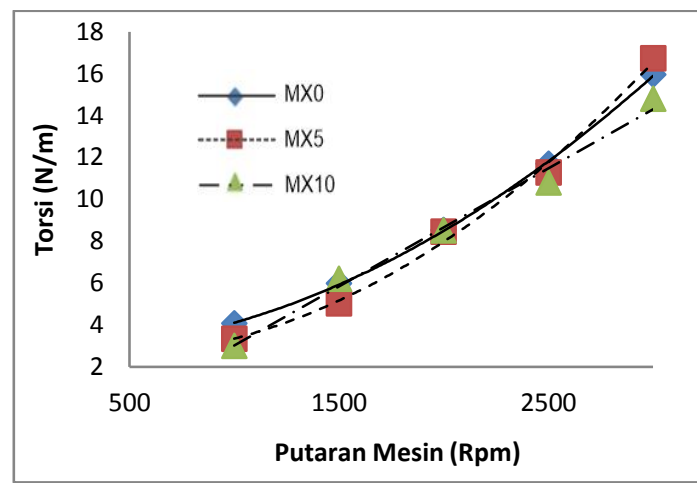

Gambar 3.3 Grafik daya vs putaran mesin untuk campuran premium etanol

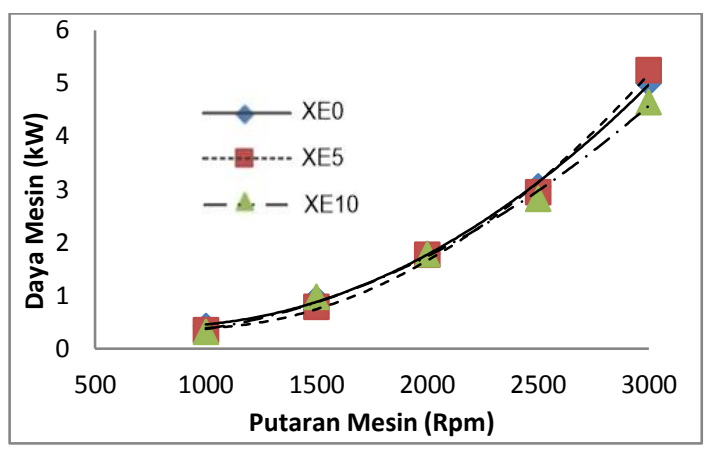

Gambar 3.4Grafik daya vs putaran mesin untuk campuran pertamax etanol

Pada daya pula terjadi sedikit penurunan pada bahan bakar campuran dibandingkan dengan bahan bakar bensin biasa. Ini terlihat pada gambar 3.3 dan 3.4. pada XE5 terjadi pernurunan sebanyak 5\% dan XE10 terjadi penurunan sebanyak 6\%. Penurunan nilai kalori bakar $(L H V)$ berakibat turun nya torsi dan daya mesin. 


\subsubsection{Konsumsi bahan bakar spesifik brek $(B S F C)$}

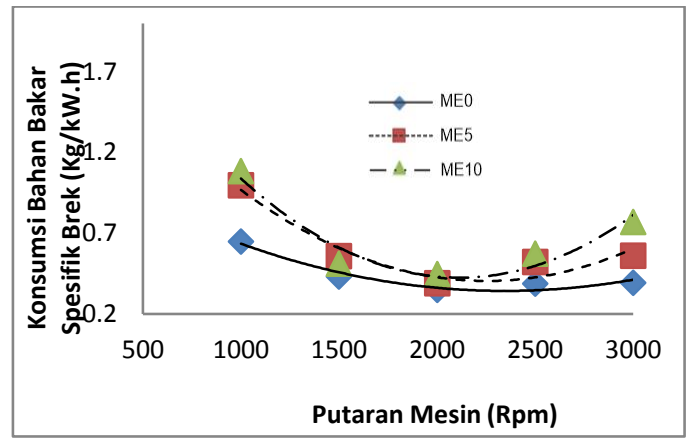

Gambar 3.5 Grafik BSFC vs putaran mesin untuk campuran premium etanol

Konsumsi bahan bakar spesifik brek $(B S F C)$ merupakan satu nilai yang menunjukan kuantitas bahan bakar yang digunakan untuk menghasilkan kerja pada mesin. Besar nya BSFC dipengaruhi oleh kualitas bahan bakar yang digunakan dan prestasi mesin. Pada gambar 3.5 menunjukan grafik konsumsi bahan bakar spesifik brek dengan variasi putaran mesin menggunakan bahan bakar murni RON88 dengan campuran etanol $5 \%$ dan $10 \%$.

Gambar 3.5 menunjukan garis grafik ME0 berada dibawah garis grafik ME5 dan ME10. Ini berarti penambahan etanol baik 5\% maupun $10 \%$ meningkatkan konsumsi bahan bakar spesifik brek mesin pada semua jenis putaran mesin.. Penambahan jenis etanol 96 yang masih banyak mengandung air $\left(\mathrm{H}_{2} \mathrm{O}\right)$ berakibat turun nya kualitas pembakaran dalam ruang bakar. Ini ditunjukan oleh nilai LHV campuran EM5 dan EM10 mengalami penurunan jika dibandingkan dengan EM0. Peningkatan konsum bahan bakar spesifik pada campuran ME5 sebesar 37\% sedangkan pada campuran ME10 terjadi peningkatan sebanyak $53 \%$.

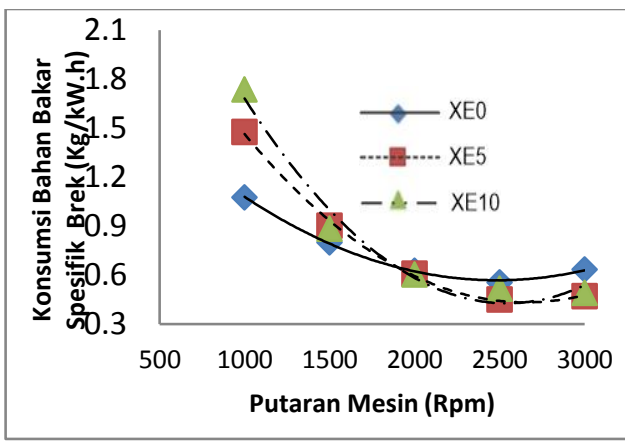

Gambar 3.6 BSFC vs putaran mesin untuk campuran pertamax etanol

Pada gambar 3.6 juga dapat dilihat grafik BSFC mesin menggunakan RON92 dengan campuran 5\% dan 10\%. Secara keseluruhan penambahan etanol pada pertamax juga menaikan konsumsi bahan bakar spesifik brek mesin. Sama seperti jenis bahan bakar premium. Tapi ada perbedaan sedikit yang ditunjukan pada gambar 3.6, garis grafik ME0 pada putaran mesin rendah ke putaran sedang, berada dibawah garis grafik XE5 dan XE10, sedangkan pada putaran tinggi, yaitu 2000Rpm - 3000Rpm garis grafik XE0 berada diatas XE5 dan XE10. Terjadi penghematan konsumsi bahan bahan bakar spesifik brek pada putaran tinggi (2000Rpm - 3000Rpm). Penambahan etanol dapat meningkatkan nilai RON bahan bakar campuran. Yang dapat membantu proses pembakaran hanya terjadi satu kali yaitu pada saat penyalaan busi sebelum piston sampai ke TMA (titik mati atas). Campuran XE5 dapat menghemat konsumsi bahan bakar sebanyak $15.8 \%$ sedangkan XE10 penghematan terjadi sebanyak $11.5 \%$.

\subsubsection{Effisiensi terma}

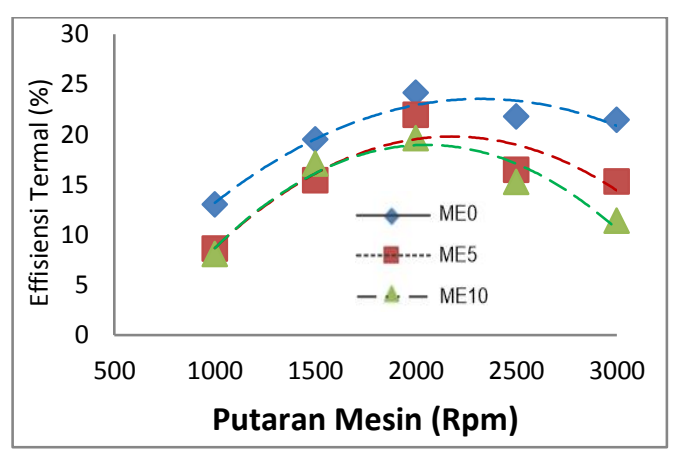

Gambar 3.7Grafik effisiensi terma vs putaran mesin untuk campuran premium etanol 


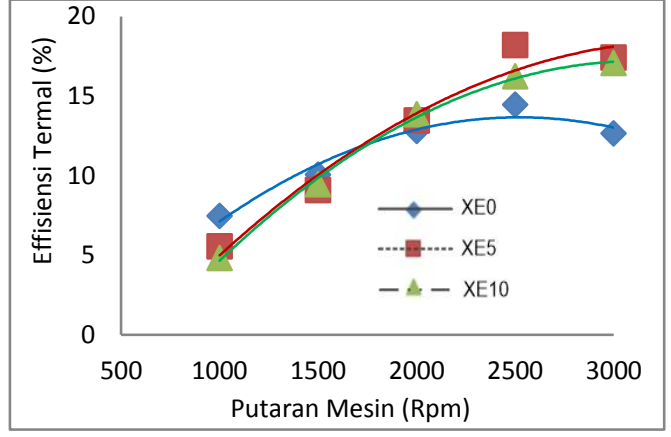

Gambar 3.8 Grafikeffisiensi terma vs putaran mesin untuk campuran pertamax etanol

Efisiensi mesin sangat dipengaruhi oleh jenis mesin dan kualitas bahan bakar yang digunakan. Pada gambar 3.7 dan 3.8 menunjukan perbandingan effisiensi mesin yang dihasilkan oleh bahan bakar bensin premium dan pertamax biasa dengan bahan bakar bensin premium dan pertamax yang dicampur dengan aditif etanol sebanyak 5\% dan $10 \%$. Pada gambar 3.7 garis grafik ME0 berada diatas garis grafik ME5 dan ME10. Fenomena ini menunjukan bahwa penambahan etanol pada bahan bakar RON88 memberikan penurunan kualitas bahan bakar dan meningkatkan konsumsi bahan bakar yaitu sebanyak $22.2 \%$ pada ME5 dan 28.5\% ME10 di semua jenis putaran mesin.

Sedangkan pada gambar 3.8 garis grafik XE0 berada diatas garis XE5 dan XE10 pada putaran mesin rendah, sedangkan pada putaran mesin sedang ke tinggi, garis grafik XE0 berada dibawah XE5 dan XE10. Ini menunjukkan penambahan aditif etanol pada bensin jenis pertamax dapat meningkatkan prestasi mesin. Penambahan sebanyak 5\% dapat meningkatkan prestasi mesin sebanyak $10.9 \%$ sedangkan penambahan $10 \%$ dapat meningkatkan effisiensi sebanyak 7\% jika dibandingkan dengan bensin pertamax biasa pada semua putaran mesin.

\section{KESIMPULAN}

Penelitian diatas dapat menunjukan pengaruh penambahan aditif etanol 96 terhadap prestasi motor bensin. Beberapa pengaruh yang diberikan oleh etanol adalah sebagai berikut :
- Terjadi penurunan torsi dan daya mesin pada campuran etanol, baik untuk RON88 maupun RON92. Penurunan yang paling kecil pada campuran etanol dan RON88 adalah ME10 yaitu 9\% untuk torsi dan $1 \%$ untuk daya., sedangkan pada pertamax penurunan terkecil pada MX5 yaitu 3\% untuk torsi dan $1 \%$ utnuk daya.

- Untuk BSFC juga terjadi penghematan konsumsi bahan bahan bakar spesifik brek pada putaran tinggi (2000Rpm 3000Rpm). Campuran XE5 dapat menghemat konsumsi bahan bakar sebanyak $15.8 \%$ sedangkan XE10 penghematan terjadi sebanyak $11.5 \%$.

- Penambahan sebanyak 5\% dapat meningkatkan prestasi mesin sebanyak $10.9 \%$ sedangkan penambahan $10 \%$ dapat meningkatkan effisiensi sebanyak 7\% jika dibandingkan dengan bensin pertamax biasa pada semua putaran mesin.

\section{DAFTAR PUSTAKA}

Anonim.2007.Bioetanol.http://www. energi.lipi.go.id/bioetanol.html.Diakses 8Maret2009. H1m22.

Arismunandar,Wiranto.1988.PenggerakMul aMotorBakarTorak,Edisi Kelima.Bandung:PenerbitITB.Hlm61

Berg, C. 2004. World Fuel EthanolAnalysis and Outlook. http://www. distill.com/world-fuelethanol-A\&O2004.html.Diakses5Maret 2017.Hlm8.

Cassanova.2008.http://www.cassanova08.co $m$.Diakses 15Juli2009.Hlm1.

Crouse,William.H.1976.AutomotiveMechani $c s$, SeventhEdition. McGrawHillBookCompany. Hlm44.

Handayani,Sri.2005.PemanfaatanBioetanolS ebagaiPenggantiBensin. http://www.biotek.lipi.go.id.Diakses 10Maret.HIm99.

Indartono,Y.2005.BioetanolAlternatifEnergi Terbarukan:KajianPrestasi

MesindanImplementasidiLapangan.http://w ww.energi.lipi.go.id.Diakses 5Maret2009. HIm25. 